UDC 621.039.75

\title{
AMERICIUM AND CURIUM BURNUP IN A FUSION REACTOR
}

\author{
V.E. Moiseenko ${ }^{1}$, S.V. Chernitskiy ${ }^{2}$, O. Agren ${ }^{3}$ \\ ${ }^{I}$ Institute of Plasma Physics, National Science Center «Kharkiv Institute of Physics and Technology», Kharkiv, Ukraine \\ ${ }^{2}$ «Nuclear Fuel Cycle» Research and Technology Division, National Science Center «Kharkiv Institute of Physics and Technology, \\ Kharkiv, Ukraine \\ ${ }^{3}$ Uppsala University, Angström laboratory, Uppsala, Sweden
}

\begin{abstract}
A large amount of spent nuclear fuel (SNF) from nuclear power plants has been accumulated globally to date, and there is still no established strategy for handling it. While SNF can be partitioned, the predominant isotope Uranium-238 can be used to produce secondary fuel in fast nuclear reactors, and plutonium be burned in thermal nuclear reactors as a part of MOX fuel. Fission products can be disposed in geological repositories, as they decay in 200 - 300 years - much sooner than SNF. A major challenge is to handle minor actinides (MAs), particularly americium and curium, which are long-lived elements and are currently not recycled. They have different nuclear properties and cannot be treated like plutonium. It is possible to have americium and curium effectively burned up (fissioned) through irradiation with fusion neutrons. This paper explores the idea of employing fusion power plants for recycling those elements. An appropriate model was generated, which used americium and curium quantities small enough to avoid any strong impact on the reactor systems and operation. At the same time, the model allowed for high MA burnup rates. Nuclear facility used in the model was a torus-shaped thermonuclear reactor with plasma major and minor radii of 1000 and $300 \mathrm{~cm}$, respectively. Such facility could take up additional $10 \mathrm{t}$ of fuel (americium plus curium) with no significant impact on its physical characteristics. The americium and curium burnup rates, calculated with the MNCPX code, were within acceptable limits. Fission neutrons were found to contribute to the production of tritium, which may be important from the standpoint of the reactor's self-sufficiency in tritium supply. Calculations proved that the reactivity of the reactor as a fission burner was low, enabling a safe operation. In addition to the MA incineration and tritium breeding capacities, fission reactions provided for a moderate (tens of percent) power gain.
\end{abstract}

Key words: fast reactors, spent nuclear fuel, fusion installations, MCNPX.

DOI: $10.21517 / 0202-3822-2021-44-2-133-138$

\section{ВЫГОРАНИЕ АМЕРИЦИЯ И КЮРИЯ В ТЕРМОЯДЕРНОМ РЕАКТОРЕ}

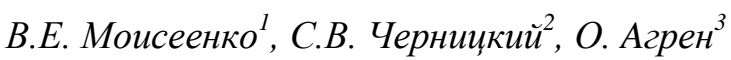

\footnotetext{
${ }^{1}$ Институт физики плазмы, Национальный научный центр «Харьковский физико-технический институт», Харьков, Украина ${ }^{2}$ Научно-технический отдел «Ядерный топливный цикл», Национальный научный центр «Харьковский физико-технический институт», Харьков, Украина

${ }^{3}$ Университет Упсаль, лаборатория Ангстрема, Уппсала, Швеция
}

В настоящее время во всём мире накоплено большое количество отработавшего ядерного топлива (ОЯТ) с атомных электростанций, и до сих пор нет установленной стратегии обращения с ним, в то время как ОЯТ может быть сепарировано, преобладающий изотоп ${ }^{238} \mathrm{U}$ может быть использован для получения вторичного топлива в быстрых ядерных реакторах, а плутоний может сжигаться в ядерных реакторах в качестве части МОКС-топлива. Продукты деления можно утилизировать в геологических хранилищах, так как они распадаются через 200-300 лет, гораздо раньше, чем ОЯТ. Основная проблема заключается в обработке минорных актинидов (МА), особенно америция и кюрия, которые являются долгоживущими элементами и в настоящее время не перерабатываются. Они обладают различными ядерными свойствами и не могут использоваться так же, как плутоний. Можно эффективно сжигать америций и кюрий (расщеплять) путём облучения термоядерными нейтронами. В настоящей статье исследуется идея создания термоядерных электростанций для переработки этих элементов. Была создана соответствующая модель, в которой использовались количества америция и кюрия, достаточно малые, чтобы избежать какого-либо сильного воздействия на реакторные системы и их работу. В то же время модель допускала высокие показатели выгорания МА. Ядерная установка, используемая в модели, представляла собой термоядерный реактор в форме тора с большим и малым радиусами плазмы 1000 и 300 см соответственно. Такая установка могла бы потреблять дополнительно 10 т топлива (америций плюс кюрий) без существенного влияния на её физические характеристики. Скорости выгорания америция и кюрия, рассчитанные с помощью кода МNCPX, находились в требуемых пределах. Было обнаружено, что нейтроны деления способствуют производству трития, что может быть важно с точки зрения самодостаточности реактора в поставках трития. Расчёты показали, что реактивность реактора была низкой, что обеспечивало безопасную эксплуатацию. В дополнение к мощностям сжигания МА и размножения трития реакции деления обеспечивали умеренный (десятки процентов) прирост мощности.

Ключевые слова: быстрые реакторы, отработавшее ядерное топливо, термоядерные установки, MCNPX.

\section{INTRODUCTION}

A large number of nuclear power reactors operating in the world require uranium «enriched» in the ${ }^{235} \mathrm{U}$ isotope for their fuel. This is not the case of research reactors and reactors used in watercraft, including submarines. The operation of thermal nuclear power plants results in large amounts of spent nuclear fuel (SNF), which conti- 
nue to grow. Nuclear power development in different countries and globally depends on approach adopted with respect to the SNF management. This paper addresses approaches already in place and those that are yet in the works and believed to be promising, with a particular focus on SNF management using thermonuclear facilities.

Nuclear power plays an important role in the world's energy supply. Its growth prospects are directly linked to the availability of proven uranium reserves. [1]. Electricity from nuclear power plants is one of the cheapest [2]. That said nuclear power is fraught with a variety of problems, including the radiotoxic nuclear waste. At present, SNF is isolated in geological repositories, where it can be stored for hundreds of thousands of years. However, SNF contains valuable chemical elements, whose extraction can potentially deliver economic benefits [3].

The incineration of transuranic elements at different levels of burnup depth is only possible in a fast neutron spectrum, because not all transuranics can be fissioned by thermal neutrons. However, this technology has some limitations that can be summarized as follows:

- transuranics contained in SNF and undergoing fission cause a deficit of delayed neutrons, which decreases the reactor controllability $[4,5]$;

- in a fast reactor, the Doppler-effect is reduced, which can be a major safety issue in the case of an accident, such as the fuel heating up in the reactor core;

- fast reactors are critical.

From the above one can conclude that transuranic elements make up only a small fraction of fast reactor fuel, which significantly reduces the rate of their transmutation. What is more, the prospect of using the scarce ${ }^{235} \mathrm{U}$ as a major fuel component is highly undesirable.

Another method to obtain high-energy neutrons is to use an accelerator driven system (ADS) [6-9]. This electronuclear breeder facility, created as an alternative to fast neutron reactors, (Fig. 1) uses a subcritical nuclear reactor coupled with a particle accelerator and a neutron producing target, which eliminates the risk of power excursion accidents. In this method, MAs, placed in the core along with ${ }^{235} \mathrm{U}$, are expected to gradually burn up. It is important to note the significant conceptual advantage of electronuclear units over traditional fast neutron reactors. In addition to being deterministically safer due to the subcritical core, an ADS allows a harder neutron spectrum to be achieved. As a result, the amount of all MAs is reduced (albeit with varying efficiency).
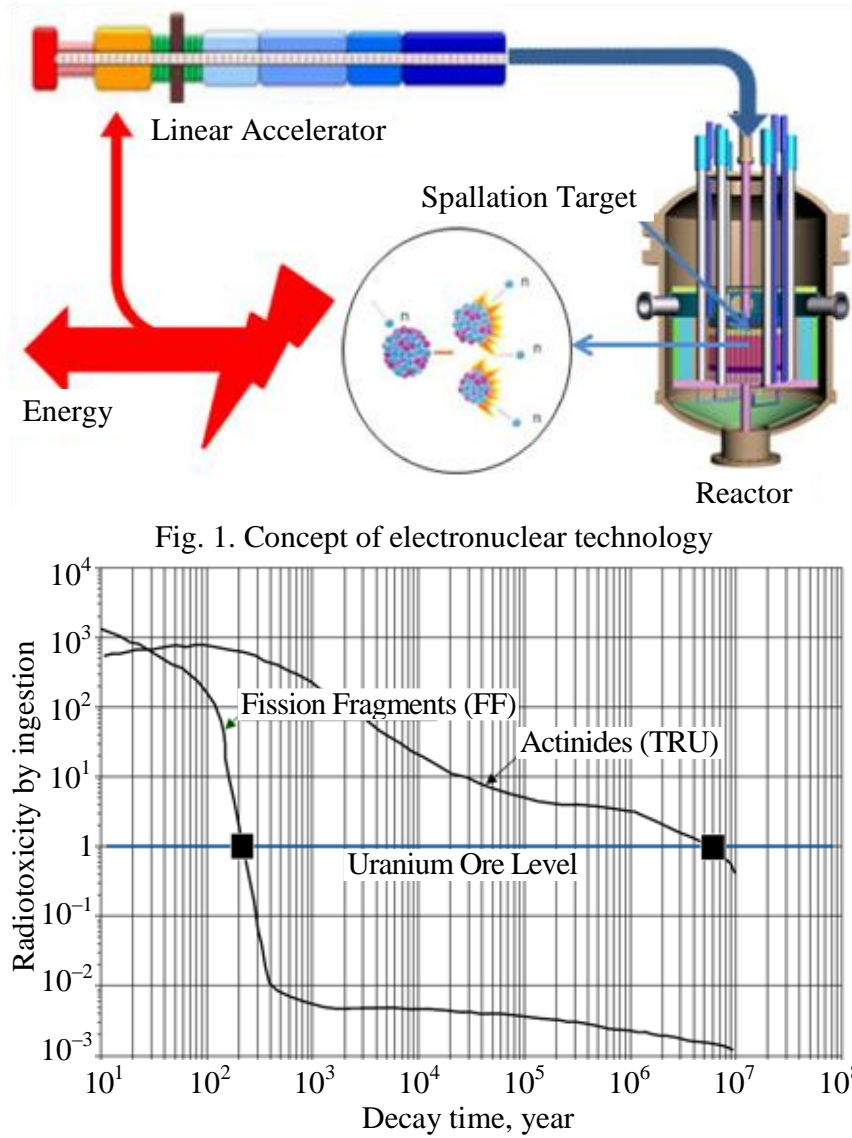

Fig. 2. Time evolution of the potential radiotoxicity (relative to uranium ore) of the two main components of nuclear waste for PWR spent fuel

The electronuclear technology has a greater degree of engineering complexity than the traditional reactor technology, as it combines accelerator technology and reactor physics, not to mention a number of related applied science disciplines.

Another technology that provides a harder neutron spectrum than the fast reactor is the fusionfission hybrid reactor [10-12]. However, the disadvantages inherent in the ADS technology are also encountered in hybrid reactors.

One SNF management technology that is extensively used worldwide is temporary storage. This is relatively cheap compared to the above options, as the fuel (17 or 24 fuel assemblies) is stored in concrete containers at nuclear power plant sites. However, storage in interim on-site facilities is limited to 100 years, and options concerning further disposing of SNF are to be decided upon at a later stage.

Spent fuel can be partitioned. The majority isotope, ${ }^{238} \mathrm{U}$, is not radioactive. Plutonium can be burned in thermal nuclear reactors as part of MOX fuel. Fission products can be disposed in geological repositories, as they decay in 200-300 years [13], much sooner than SNF (Fig. 2). A major challenge is to handle MAs, particularly americium and curium. 
The aim of the study was to analyze the possibility of burning significant quantities of americium and curium isotopes in a tokamak-type fusion reactor with dimensions close to DEMO and figure out whether fusion power plants can be utilized for a deep burnup of americium and curium isotopes. The amounts of americium and curium isotopes to be present in the reactor were chosen to be small enough to avoid any strong impact on the reactor systems and operation.

\section{FUSION REACTOR MODEL}

Computer simulations were performed with the Monte - Carlo N-Particle extended (MCNPX) code [14], which supports problems involving the transport of radiation from a volumetric source of arbitrary spectral composition in complex three-dimensional models. It uses the Monte-Carlo method for the solution of radiative transfer equations and allows for continuous-energy treatment and flexible geometry modelling.

Our neutronic model has a two-dimensional cylindrically symmetric geometry. Its radial structure is shown in Fig. 3. The model dimensions are close to those of the future DEMO reactor. The vacuum chamber contains a D-T-plasma which is the source of fusion neutrons. The first wall, chosen to be $3 \mathrm{~cm}$ thick, was assumed to be made of HT-9 steel with a mass density of $7.7 \mathrm{~g} / \mathrm{cm}^{3}$. Its isotopic composition was taken from the ORNL Fusion materials data bank [15]. The HT-9 steel is a candidate structural material for the first wall of the ITER experimental thermonuclear reactor.
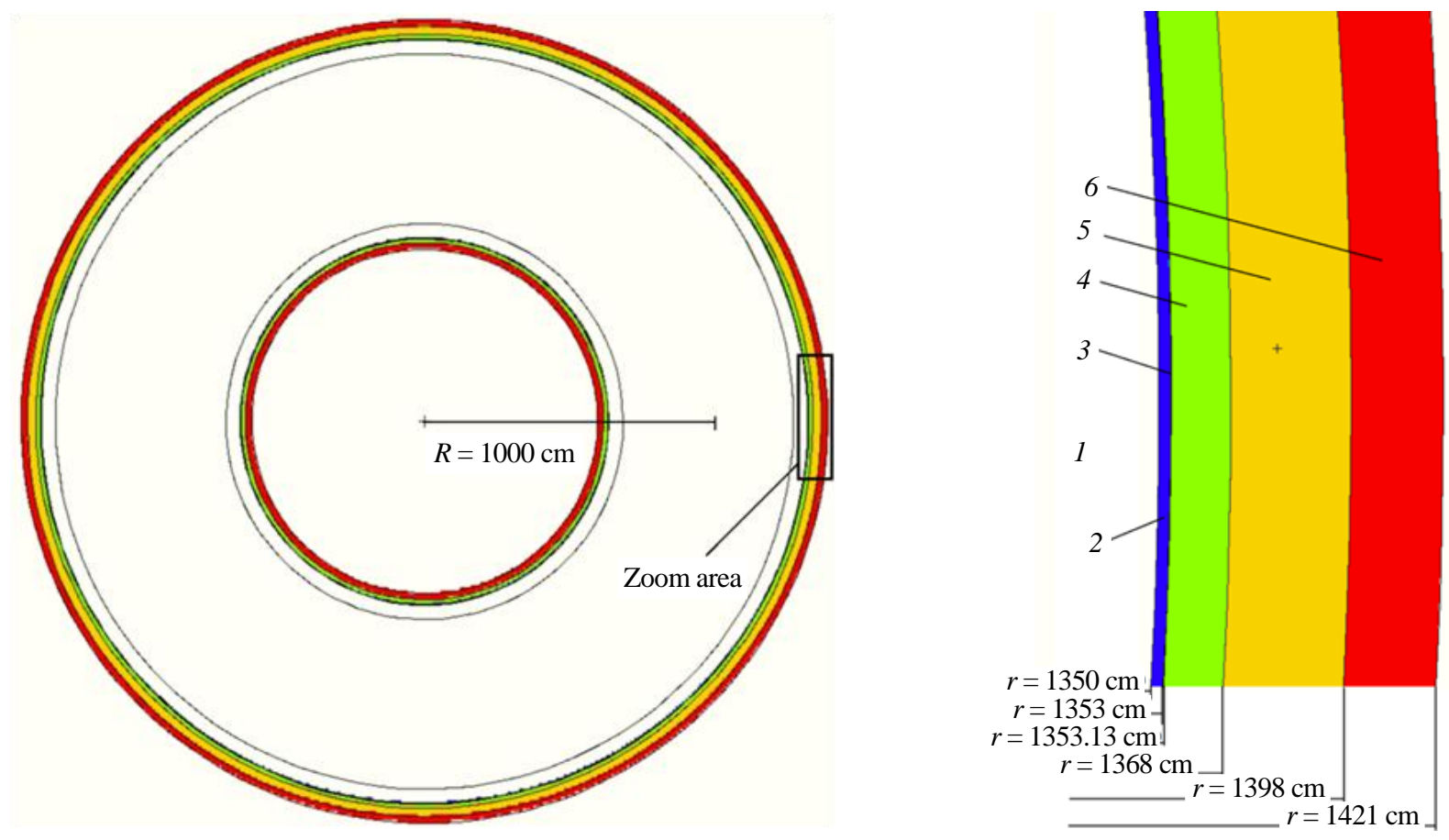

Fig. 3. Radial cross-section of the model: 1 - vacuum chamber; 2 - first wall; $3-\mathrm{Am}+\mathrm{Cm}$; $4-\mathrm{LBE}$; $5-$ natural lithium; 6 - shield

The thickness of the reactor core (blanket) containing the americium and curium isotopes was determined from critically calculations. A thickness of $0.13 \mathrm{~cm}$ was found to provide the effective multiplication factor $k_{\text {eff }} \approx 0.1$. Behind the blanket, there is a lead-bismuth-eutectic (LBE) system, which is $15 \mathrm{~cm}$ thick. The LBE system is assumed to be made of $44.5 \% \mathrm{wt}$. lead and $55.5 \% \mathrm{wt}$. bismuth and have a mass density of $10.17 \mathrm{~g} / \mathrm{cm}^{3}$ [16]. In addition to its primary role in the LBE system, lead acts as a fast neutron flux amplifier due to the neutron propagation threshold reaction ${ }^{208} \mathrm{~Pb}(n, 2 n){ }^{207} \mathrm{~Pb}$. The buffer zone was chosen to be $15 \mathrm{~cm}$ thick for the reason that a fast neutron's free path within the LBE is $15 \mathrm{~cm}$ long. In general, using liquid metal as a coolant in a high-temperature reactor has many advantages. High boiling point, significant heat capacity, and good thermal conductivity are more or less inherent in liquid metals. Bismuth and lead have melting points of $271{ }^{\circ} \mathrm{C}$ and $327^{\circ} \mathrm{C}$, respectively, whereas the eutectic lead-bismuth alloy melts at $125^{\circ} \mathrm{C}$. Therefore, LBE is less prone to solidify in the reactor cooling circuit, than pure lead. 
Continuous tritium reproduction is very important to maintain a self-sufficient operation of the plasma neutron source. Due to tritium's low $(\sim 20 \mathrm{keV})$ beta decay energy [17], particles emitted from this decay are easily stopped by ordinary clothing or rubber surgical gloves. However, this isotope presents a radiation hazard when inhaled and ingested with food [18]. Therefore, tritium transportation may be dangerous. In addition, tritium is an expensive material (around USD 30000 per gram) [19]. For this reason, it is worthwhile to arrange for tritium reproduction inside the hybrid reactor and on-site handling in addition to ensuring the plasma source selfsufficiency.

Tritium is produced through the following four reactions:

$$
\begin{aligned}
& \text { 1. }{ }^{6} \mathrm{Li}+n \rightarrow{ }^{4} \mathrm{He}+\mathrm{T} ; \\
& \text { 2. }{ }^{10} \mathrm{~B}+n \rightarrow 2{ }^{4} \mathrm{He}+\mathrm{T} ; \\
& \text { 3. }{ }^{14} \mathrm{~N}+n \rightarrow{ }^{12} \mathrm{C}+\mathrm{T} ; \\
& \text { 4. }{ }^{7} \mathrm{Li}+n \rightarrow{ }^{4} \mathrm{He}+\mathrm{T}+n .
\end{aligned}
$$

The cross-section of the thermal neutron reaction for ${ }^{6} \mathrm{Li}$ is about 940 barn, 70 barn for natural lithium and only $5 \cdot 10^{-3}$ barn for ${ }^{10} \mathrm{~B}$. The reaction ${ }^{14} \mathrm{~N}(n, \mathrm{~T}){ }^{12} \mathrm{C}$ is a threshold reaction (requiring a minimum energy of incident neutrons $>4 \mathrm{MeV}$ ), and for neutron energies $E_{n}=5-7 \mathrm{MeV}$, the reaction cross section is only $2 \cdot 10^{-2}$ barn. The reaction ${ }^{7} \mathrm{Li}\left(n, n^{\prime} \mathrm{T}\right)$ is a threshold one and requires $>2.8 \mathrm{MeV}$ of incident neutron energy to start. Thus, the predictable and optimal way to produce tritium is through the ${ }^{6} \mathrm{Li}(n, \mathrm{~T})$ reaction. The tritium breeding zone is $30 \mathrm{~cm}$ thick and filled with natural lithium. Calculations suggest that no additional lithium 6 enrichment is required.

A $23 \mathrm{~cm}$-thick shield is used to reduce the neutron and gamma loads of the tokamak magnetic coils needed for the plasma confinement. The shield contains 304B7 alloy (UNS S30467) stainless steel [20] and water, 60:40 vol. \%. The steel component has $1.75 \%$ wt. of natural boron. The protection zone is also used to provide supplementary external cooling for the entire installation.

All volumetric elements of the fusion reactor were modeled as a homogeneous mixture of its component materials. Because of the neutrons' long mean free path, such modeling is acceptable for fast systems and does not distort the result, and also significantly reduces the calculation time.

\section{CALCULATION RESULTS}

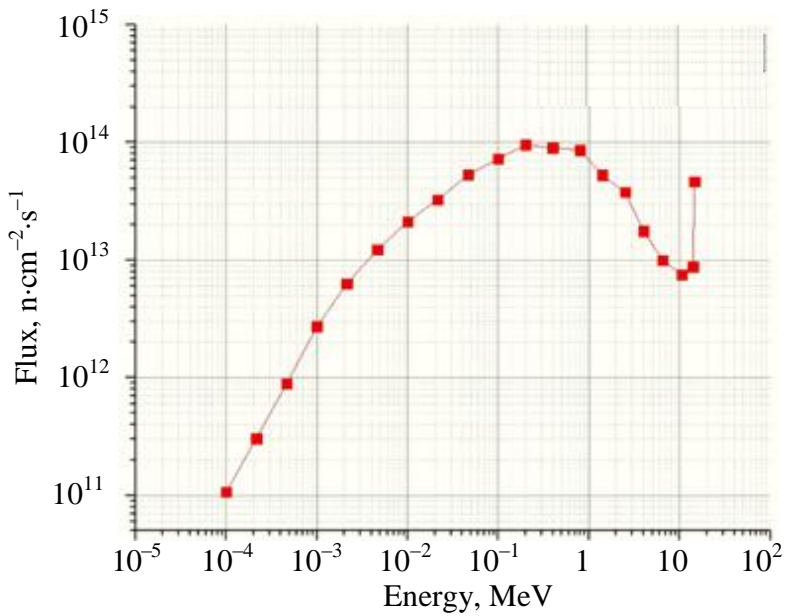

Fig. 4. Neutron spectrum at the blanket
The probability of any reaction depends on incident particle's energy. In our case, knowing the neutron spectrum in the vicinity of the americium and curium isotopes' location is important, as this allows the burnup rates for those isotopes to be estimated.

Americium and curium isotopes can be effectively fissioned by neutrons with energies higher than $0.5 \mathrm{MeV}$, especially those falling under the «thermonuclear» spectrum. As can be seen from Fig. 4, the number of neutrons with energies above $0.5 \mathrm{MeV}$ is significant. It is interesting to compare the number of source neutrons and their energy for the discussed tokamak model and, for example, for a PWR-type thermal reactor (Table 1).

T a b l e 1. Source neutron comparison

\begin{tabular}{l|c|c}
\hline \multicolumn{1}{c|}{ Reactor type } & Numbers of neutrons & Neutron energy, MeV \\
\hline Fusion (DEMO) & $1.0 \mathrm{E} 21$ & 14 \\
PWR & $3.0 \mathrm{E} 19$ & 0.7 \\
\hline
\end{tabular}

As one can see from Table 1, a fusion reactor is a sound candidate for the role of a burner system for americium and curium. Column 2 in Table 2 shows the percent content of americium and curium in SNF extracted from PWR reactors. Column 3 shows the mass of each isotope loaded in a fusion reactor. When the specified amounts are loa- 
ded, it appears that the reactor is deeply subcritical $\left(k_{\text {eff }}=0.091\right)$, with the thermal fission power at $0.425 \mathrm{GW}_{\text {th }}$, that is, about $15 \%$ of the fusion power ( $2.7 \mathrm{GW}_{\text {th }}$ in our model). Such a low subcriticality makes the reactor safe. The additional fission power is not large and does not require big changes to the cooling system. Column 4 in Table 2 shows how the concentration of a given isotope in fuel decreases after one year of the facility continuous operation.

$\mathrm{T}$ a b l e 2. Source neutron comparison

\begin{tabular}{c|c|c|c|c}
\hline Element & Wt.\% & Fuel load, $\mathrm{kg}$ & Burnup after one year of operation, $\%$ & Fusion neutron source intensity, $\mathrm{s}^{-1}$ \\
\hline${ }^{241} \mathrm{Am}$ & 88.796 & 9390 & 7.0 & $1.0 \cdot 10^{21}$ \\
${ }^{242} \mathrm{Am}$ & 0.06478 & 6.85 & 70 & \\
${ }^{243} \mathrm{Am}$ & 9.87 & 1040 & 6.2 & \\
${ }^{243} \mathrm{Cm}$ & 0.0174 & 1.83 & 12.8 & \\
${ }^{244} \mathrm{Cm}$ & 1.12 & 118 & 3.7 & \\
${ }^{245} \mathrm{Cm}$ & 0.121 & 12.7 & 8.2 & \\
${ }^{246} \mathrm{Cm}$ & 0.00967 & 1.01 & 1.9 & \\
\hline
\end{tabular}

The model used natural lithium for the tritium breeding zone, which allowed a tritium breeding ratio of 1.34 to be obtained. This should be enough to produce tritium needed for the plant's own needs.

\section{CONCLUSIONS}

So far, about $400000 \mathrm{t}$ of SNF have been discharged from commercial nuclear power reactors, of which $100000 \mathrm{t}$ have been reprocessed. Considering that americium and curium account for about $0.1 \%$ of SNF, some $300 \mathrm{t}$ of these materials should be available for transmutation purposes. The proposed method for americium and curium incineration in tokamaks does not seem to be about to perturb the operation of future tokamak-based fusion reactors in any significant way. The fusion reactor fleet should digest and remove part of SNF that is, accomplish something that other facilities are unable to do.

\section{REFERENCES}

1. Sukhodolov A.P. World's supply of uranium: prospects for primary provision of atomic energy industry. - Izvestiya of Irkytsk State Economics Academy, 2010, № 4, 72 p.

2. Glukhov V.V., Barykin S.E. The economics of electropower complex. - StPb: Pub.house of StPb SPU, 2003. 206 p. (in Russian).

3. Kolarik Z., Renard E.V. Potential applications of fission platinoids in industry. — Platinum Metals Review. 2005, vol. 49, p. 79-90.

4. Sandmayer A.G. Kinetics and stability of fast neutron reactors. - M.: «Publishing by atom. Science and Technology», 1963.

5. Toshinskiy G., Bulavin P. - Nuclear Energy, 1967, vol. 23, Iss. 2, p. 146-149.

6. Barashenkov V.S. Problems of electronuclear technology. Preprint JINR P2-94-56. — Dubna, 1994 (in Russian).

7. Barashenkov V.S. Nuclear-physical aspects of electronuclear method. - Particles \& Nuclei, 1978, vol. 9, issue 5 (in Russian).

8. Vasil'kov R.G., Gol'danskiy V.I., Orlov V.V. About the electric breeding. - UFN (APhS), 1983, vol. 139, issue 3 (in Russian).

9. Vasil'kov R.G., Gol'danskiy V.I., Dzhelepov V.P., Dmitrievskiy V.P. Electronuclear method of neutrons generation. Atomnaya energiya (Atomic energy), 1970, vol. 29, issue 3 (in Russian).

10. Qiu L.J., Yang Y.W., Wu Y.C. A compact tokamak transmutation reactor for treatment of high level wastes. — Plasma Physics and Controlled Nuclear Fusion Research. Proceedings of the Fifteenth International Conference, 1994, vol. 2.

11. Stacey W.M., Hoffman E.A. Tokamak transmutation facility studies. — Fusion Technology, 2001, vol. 39(2P2), p. 525-529.

12. Azizov E.A., Gladush G.G., Lopatkin A.V., Lukasevich I.B. Tokamak based hybrid systems for fuel production and recovery from spent nuclear fuel. - Atomic Energy, 2011, vol. 110(2), p. 93-98.

13. Ishkhanov B.S. Radioactivity. - M.: Publishing University Book, 2011.

14. For the U.S. Department of Energy. Monte-Carlo N-Particle Transport Code System for Multiparticle and High Energy Applications, Version 2.4.0. Los Alamos National Laboratory, Los Alamos report LA-CP-02-408, 2002.

15. ORNL, Fusion Materials, 1999; http://www.ms.ornl.gov/programs/fusionmtlspdf/june1999/hashimoto1.pdf.

16. OECD NEA, 2007; http://www.nea.fr/html/science/reports/2007/pdf/chapter2.pdf.

17. Audi G., Wapstra A.H., Thibault C. The AME2003 atomic mass evaluation (II). Tables, graphs and references. — Nuclear Physics A, 2003, vol. 729, p. 337-676.

18. Osborne R.V. Tritium Hazard Report: Pollution and Radiation Risk from Canadian Nuclear Facilities. Canadian Nuclear Association, 2007.

19. Rogers Abby. The 16 Most Expensive Substances in the World. URL: www.businessinsider.com/most-valuable-substances-byweight-2011-11?op=1.

20. Fix D.V. et al. LLNL report UCRL-PROC-202920, 2004. 


\section{AUTHORS}

Vladimir E. Moiseenko, Institute of Plasma Physics, National Science Center «Kharkiv Institute of Physics and Technology», Akademichna st. 1, 61108 Kharkiv, Ukraine, moiseenk@ipp.kharkov.ua

S.V. Chernitskiy, «Nuclear Fuel Cycle» Research and Technology Division, National Science Center «Kharkiv Institute of Physics and Technology», Akademichna st. 1, 61108 Kharkiv, Ukraine

O. Ågren, Uppsala University, Ångström laboratory, Box 534, SE 75121 Uppsala, Sweden

Received 15 January 2021

Revised 16 March 2021

Accepted 25 March 2021

Problems of Atomic Science and Technology Ser. Thermonuclear Fusion, 2021, vol. 44, issue 2, pp. 133-138 